\title{
How to minimize pterygium recurrence rates: clinical perspectives
}

This article was published in the following Dove Press journal:

Clinical Ophthalmology

\section{Raffaele Nuzzi \\ Federico Tridico}

S.C.U. Ophthalmology Unit, "City of Health and Science" University Hospital, Department of Surgical Sciences, University of Turin, Turin, Italy
Correspondence: Raffaele Nuzzi

S.C.U. Oculistica - A.O.U. Città della

Salute e della Scienza, Via Cherasco 23,

10126 Turin, Italy

Tel +3936 8203493

Email prof.nuzzi_raffaele@hotmail.it

\begin{abstract}
The main treatment for pterygium is surgical removal. However, pterygium surgery is concerned with high rates of postoperative recurrence. Predicting factors of recurrence are not fully understood, yet, but they probably depend on a multitude of patient-related, clinical, and/or surgical factors. Several adjuvant treatments have been proposed to reduce postoperative pterygium recurrence, including different antimetabolites, antiangiogenetic factors, and radiation therapy. The purpose of this review is to collect the current evidence regarding application and limits of different therapeutic approaches for preventing postoperative recurrence of pterygium, giving insights and perspectives for better management of this disease. In the light of the current evidence, pterygium surgery cannot disregard wound coverage with conjunctival autografting or rotational flap combined with adjuvant treatments. The rotational flap technique is associated with shorter surgical time rates and prevents graft displacement and necrosis, given its vascular pedicle. Amniotic membrane may still be reserved in case of great conjunctival defects or insufficient conjunctiva. Repeated subconjunctival antivascular endothelial growth factor injections can be considered as an effective and safe adjuvant treatment. Moreover, management of postoperative pain is crucial. Innovative treatment strategies will probably target different molecular pathways, considering recent findings regarding pterygium pathogenesis, to improve better understanding and develop universally shared guidelines. Great importance shall be dedicated to the identification of novel molecular biomarkers and favoring factors of recurrence, in order to achieve a customized surgical treatment for each patient and obtain maximal reduction of postoperative recurrence.
\end{abstract}

Keywords: pterygium, conjunctival autograft, rotational flap, amniotic membrane, adjuvant therapy, predicting factors

\section{Introduction}

Pterygium is an abnormal growth of epithelial and fibrovascular tissue invading the cornea across the limbus and can lead to impaired vision (due to excessive dimensions or induced astigmatism) or recurrent inflammation. Pterygium formation is thought to be the result of altered epithelial cell proliferation and altered vascularization. ${ }^{1-5}$ However, the precise pathogenesis of this disease is still unclear.

Pathogenic factors related to pterygium formation include ultraviolet (UV) radiation (as observed in numerous studies, probably through damage to DNA, proteins and lipids, both direct or induced by reactive oxygen species), ${ }^{6-10}$ viral infections (mainly herpes simplex virus, cytomegalovirus, and human papillomavirus), ${ }^{11-13}$ epigenetic aberrations, transition from epithelial to mesenchymal tissue, ${ }^{14}$ inflammatory and antiapoptotic mechanisms, ${ }^{15-18}$ neoangiogenic upregulation, ${ }^{2,19}$ stimulation of lymphangiogenic response, ${ }^{20}$ deregulation of extracellular matrix modulators, ${ }^{21}$ growth factors, ${ }^{22-25}$ recruitment of bone marrow-derived stem and progenitor cells, ${ }^{26,27}$ and modifications 
in cholesterol metabolism. ${ }^{28}$ Moreover, Anguria et al reported that hereditary predisposition may be fundamental for the onset and persistence of pterygium. ${ }^{29}$

The main treatment for pterygium is surgical removal, which has to be taken into consideration in case of reduced visual acuity due to visual axis involvement, induced astigmatism, or frequent inflammation and discomfort. Surgical techniques include bare sclera excision, conjunctival autograft, conjunctival transpositional flap, and amniotic membrane grafting. ${ }^{30}$ However, pterygium surgery is concerned by postoperative recurrence (whose rate can be up to $89 \%$ and its severity may vary according to the adopted approach and preoperative conditions) because fibrovascular growth may occur also with greater extension than its primary presentation. ${ }^{31}$

Predicting factors of recurrence are not fully understood, yet, but they probably depend on a multitude of patient-related (genetics, environment) and/or surgical factors. ${ }^{32}$ Among patient-related factors, ethnicity is considered a significant predisposing feature (Hispanics and dark-skinned individuals are the mostly affected). ${ }^{33}$ Other patients' characteristics associated with higher recurrence are young age, current active growth, preexisting disfiguration of lacrimal caruncle, ocular motility restriction, concurrent ocular surface inflammation, fibrogenic constitution, and family history. ${ }^{34}$

According to a grading system developed by Tan et al, a fleshy-like aspect of the pterygium is correlated with high recurrence rates, especially after bare sclera excision. ${ }^{35}$ Greater vertical size of pterygium was also associated with a higher recurrence rate. ${ }^{34}$ Moreover, different biomarkers (which are involved in reduced inhibition of epithelial and fibroblastic proliferation) are associated with higher recurrence rate. For example, excessive levels of stromal cell-derived factor 1 (which promotes TGF- $\beta$ expression) and angiogenin were observed in pterygium fibroblasts. ${ }^{36}$ As of today, additional studies are needed to further evaluate biomarkers before their application in clinical practice because histological and immunohistological features are still not sufficient to reliably predict recurrence predisposition.

Several adjuvant treatments have been proposed to reduce postoperative pterygium recurrence, including different antimetabolites, antiangiogenetic factors, radiations, as well as other novel materials and administration methods. The purpose of this review is to collect the current evidence regarding application and limits of different therapeutic approach for preventing postoperative recurrence of pterygium, giving insights and perspectives for better management of this disease.

\section{Surgical treatment Bare sclera technique}

The bare sclera technique is the first technique adopted for pterygium removal and is characterized by simple excision, allowing the scleral bed to re-epithelialize. However, this technique tends to favor postoperative pterygium proliferation because small tissue residues may be left in the scleral bed, resulting in high recurrence rates $(24 \%-89 \%){ }^{37}$ A reduction of recurrence rates - as suggested by several authors - can be obtained by combination of excision with accurate Tenon and fibrotic tissue removal. ${ }^{32}$ Nevertheless, a recent research reported that bare sclera technique was associated with higher recurrence rates, which became lower when adjuvant treatments were used. ${ }^{37}$ The bare sclera technique can be easily performed with short surgical time (depending on pterygium size), and it is appealing for trainee surgeons, but it is currently rarely applied, given the high risk of recurrence. In fact, a meta-analysis of randomized controlled clinical trials comparing bare sclera technique and conjunctival autograft demonstrated that the risk of recurrence following surgical treatment is significantly higher (ranging from 6 to 25 times) when no graft placement is performed. ${ }^{38}$ In order to achieve better postsurgical outcomes and lesser recurrences, bare sclera technique must be associated with adjuvant treatments or alternative surgical techniques featuring complete coverage of the conjunctival defect.

\section{Conjunctival autograft}

Conjunctival autografting was first described in 1985 by Kenyon et al. This technique involves the realization of a free autograft from nearby conjunctiva that will be applied over the exposed scleral bed once pterygium excision has been performed. ${ }^{39}$ This procedure is associated with lower recurrence rates when compared with the bare sclera excision alone, with more long-term efficacy. Even if recurrence rates after conjunctival autograft vary among different clinical studies, this technique is often considered to be the most effective method for pterygium treatment.

Syam et al reported a recurrence rate of $3.3 \%$ in their study, similar to the results obtained in a case series conducted by Bilge, ${ }^{40}$ while Koranyi et al, Fernandes et al, Ma et al, and Al Fayez reported $13.5 \%, 12.2 \%, 5.4 \%$, and $8.3 \%$ recurrence rates, respectively. ${ }^{31,41-43}$ However, much higher recurrence rates have been reported (ranging from $31.3 \%$ to $33.3 \%$ ), in case of recurrent pterygium excision. ${ }^{40}$ A novel technical variant named "pterygium extended removal followed by extended conjunctival transplantation" (P.E.R.F.E.C.T.) was 
conducted in Australia, with reports of patients' follow-up longer than 1 year and a recurrence rate of $1.6 \%{ }^{44}$

Although conjunctival autografting is effective in preventing pterygium recurrence, this technique requires technical expertise and extended operative time due to fixation of conjunctival autograft, especially when sutures are used. In fact, because of the need for graft fixation, the surgical time dedicated to conjunctival autograft can be longer than the one needed for simple bare sclera excision. Moreover, although rarely, the graft can be displaced or lost. Conjunctival autografts can be fixated at the level of the scleral bed through different methods. Usually, sutures are associated with postoperative discomfort, chronic inflammation, and granuloma formation. ${ }^{45}$ Fibrin glue is an alternative, synthetic adhesive (prepared from a donor plasma), first described for pterygium surgery by Cohen and McDonald in 1993. ${ }^{46}$ Koranyi et al confronted conjunctival autograft fixation using fibrin glue adhesive with suture-assisted fixation, reporting that fibrin glue had a 5.3\% recurrence rate while sutureassisted procedures were associated with a recurrence rate of $13.5 \%{ }^{47}$ Fibrin glue fixation requires a shorter operation time, but its drawbacks include potential risk of infections, hypersensitivity reactions, potential risk for dehiscence, and higher costs. ${ }^{48-50}$ Another fixation method that has been proposed is the in situ blood coagulum technique. This method has the advantages of eliminating the risk of transmitted infections and hypersensitivity reactions by using the patient's own clotting factors. Several studies have reported that recurrence rates of fibrin glue-assisted conjunctival autografting and in situ coagulum were similar; however, the use of autologous blood was associated with higher risk of graft displacement and retractions. ${ }^{51-53}$ In situ blood coagulum has similar recurrence rates and lesser postoperative discomfort when compared with suture-assisted procedures, but complications related to graft failure and graft retractions were still more common after the use of in situ blood coagulum, although the difference was not statistically significant. ${ }^{51}$ Kumar and Singh concluded that fibrin glue remains the most effective method for conjunctival autograft fixation in pterygium surgery with least surgical time and postoperative discomfort. ${ }^{45}$ The use of sutures is related to maximal surgical time and postoperative discomfort while providing better graft stability, but recurrence rates are lower with fibrin glue-assisted fixation. ${ }^{54}$ Cauterization is another surgical option, but it is still necessary to assess whether this method may be superior to fibrin glue. A clinical trial has been recently presented in order to evaluate the feasibility of this method in comparison with fibrin glue. ${ }^{55}$
Currently, graft edema, graft necrosis, graft displacement or loss, inclusion cysts, subconjunctival hematoma, Tenon's granuloma, giant papillary conjunctivitis, corneal narrowing, and Dellen ulcers have been reported to be the most common postoperative complications of primary pterygium surgery. ${ }^{56,57}$ Conjunctival granuloma (CG) is an uncommon complication of pterygium excision combined with a conjunctival autograft. Mullins et al reported a prevalence of $2 \%$ of postoperative granulomas in their study. ${ }^{58} \mathrm{In}$ a case series of 100 patients who underwent surgical treatment, a total of 52 eyes developed CGs after pterygium surgery, of which 3 were recurrent pterygium eyes. ${ }^{59} \mathrm{Zhang}$ et al reported that the incidence of CGs in primary pterygium eyes was $1.3 \%$ and $2.2 \%$ in the case of recurrent pterygia surgery. ${ }^{60} \mathrm{Common}$ causes of granulation tissue development are foreign bodies of several origins (suture material or filaments); laxly sutured conjunctival wounds with exposition of sclera and fascia tissue; uneven graft tissue edges; irregular conjunctival stitches; lack of local blood supply; inflammation, infection, or other minor factors (such as suture type and other foreign bodies) ${ }^{60,61}$ When conjunctival autograft is associated with an excessive use of mitomycin $\mathrm{C}$, avascular scleral stromalysis may occur. However, even if recurrent cases with cicatricial strabismus may occur, conjunctival autograft in combination with mitomycin $\mathrm{C}$ presents low recurrence rates and must be taken into consideration. ${ }^{62}$

It has been shown that after a very long follow-up of almost two decades there are no significant differences regarding postoperative recurrences or complications when using upper or lower conjunctiva for grafting, even if larger studies are required in order to confirm these results. ${ }^{63,64}$ Moreover, it is possible that patients who underwent excision with lower flap reported less postoperative discomfort because the upper eyelid has a greater range of motion than lower eyelid, which might lead to a more intense inflammation, tear film instability, dry eye symptoms, and longer corneal epithelial healing time. ${ }^{64}$ In the light of these considerations, conjunctival autograft in pterygium surgery can be associated with potential drawbacks. Closure of large defects is difficult, and the conjunctiva must be preserved for the possibility of glaucoma filtering surgery. Syam et al found that $36.66 \%$ of patients developed conjunctival scarring at the site of the donor conjunctiva. ${ }^{65}$ For this reason, in case of patients who may benefit from glaucoma filtration surgery, it is more advisable to utilize inferior conjunctival portions for autografting. In addition, it is not feasible to use this technique to cover wide ocular surface defects occurring in cases of large or double-headed pterygia. 
According to Paracha et al, recurrence rates of the conjunctival autograft method were similar to those achieved when mitomycin was used in association with the bare sclera technique. ${ }^{66}$ Moreover, this technique has a lower recurrence rate when compared with the application of amniotic membrane or simple bare sclera excision. ${ }^{67,68}$ Finally, combination of conjunctival autograft with intraoperative mitomycin $\mathrm{C}$ proved to be more effective in reducing recurrence rates than cases in which the two techniques are separately applied. ${ }^{69,70}$

\section{Amniotic membrane}

Amniotic membrane is the innermost layer of the placenta (featuring a thick basement membrane and an avascular stromal matrix), which can be used as a graft with antiinflammatory and antifibrotic properties, capable of providing numerous growth factors, and promoting proliferation and differentiation of epithelial cells without the risk of immunological reactions. Amniotic membrane stromal matrix is effective in suppressing the expression of TGF- $\beta$ signaling and myofibroblast transformation in pterygium. ${ }^{71,72}$ Other studies have shown that amniotic membrane facilitates epithelialization, maintains normal epithelial phenotype, and reduces inflammation, scarring, and vascularization. ${ }^{37,73,74}$ Given these features, human amniotic membrane has been considered useful in several ophthalmic surgeries, including pterygium and other conjunctival diseases. ${ }^{75}$ Typically, it must be placed over the bare sclera, with the basement membrane facing up and the stroma facing down. Fibrin glue may be also used to promote amniotic membrane graft fixation to the underlying sclera.

The application of amniotic membrane appears to be safe and effective, and it is associated with lower recurrence rates when compared with the bare sclera technique..$^{76,77}$ The reported recurrence rates with amniotic membrane graft vary between $3.8 \%$ and $40.9 \%$. In a prospective study, Prabhasawat et al reported a recurrence rate of $10.9 \%$ after amniotic membrane apposition. ${ }^{73}$ Solomon et al subsequently modified the technique achieving a lower recurrence rate of $3 \%{ }^{78}$ However, when compared with conjunctival autografts, amniotic membrane efficacy remains controversial. ${ }^{79}$

In fact, four randomized clinical trials examined pterygium recurrence rates after amniotic membrane grafts compared with conjunctival autograft procedures. All four studies showed a lower pterygium recurrence rate in conjunctival or limbal autograft groups $(P=0.05) .{ }^{80-83} \mathrm{Ma}$ et al retrospectively evaluated the efficacy and safety of amniotic membrane compared with conjunctival autograft and topical $0.02 \%$ mitomycin $\mathrm{C}$, after excision of primary pterygium, with no significant difference in recurrence rates among the groups under study ${ }^{42}$ Given these considerations and comparable recurrence rates in the literature, pterygium excision associated with amniotic membrane is a less tedious and less time-consuming method, providing the possibility of conjunctival sparing, especially needed in case of future glaucoma surgery.

Inhibition of aberrant neovascularization, prevention of inflammation, and promotion of conjunctival reepithelialization are the main reasons for amniotic membrane effects in pterygium surgery ${ }^{84-86}$ Conjunctival autografting may provide a source of conjunctival epithelium, whereas amniotic membrane seems to play a role in inhibiting the development of progenitor cells involved in pterygium recurrence. ${ }^{87}$ The procedural time of this technique can be potentially shorter, and it is technically easier to perform than conjunctival autografting. Even if results presented in the literature indicated similar visual acuity changes and epithelial healing with the amniotic membrane technique when compared with conjunctival autografting, greater inflammation and higher recurrence rates were seen in the amniotic membrane group.$^{88}$ Moreover, conjunctival autografting was more effective than amniotic membrane to prevent pterygium recurrence after a 6-month follow-up, especially in recurrent pterygia. ${ }^{79}$ Even so, amniotic membrane application may still be useful to cover large conjunctival defects after pterygium excision and to preserve conjunctiva in glaucomatous patients. Future studies should assess changes in patient-reported discomfort and visual acuity, evaluating the effects of different surgical variations.

Amano et al showed a recurrence rate of $8.7 \%$ when intraoperative $0.04 \%$ mitomycin C was associated. ${ }^{89}$ This approach reduced mitomycin $\mathrm{C}$ dosage to avoid overspill to the entire ocular surface. Coupled with short exposure to mitomycin $\mathrm{C}$, amniotic membrane can be considered as a feasible alternative for pterygium surgery, as shown in a case series by Rosen. ${ }^{90}$ Amniotic membrane grafts have been also used as an adjuvant procedure in combination with conjunctival autografting, in order to improve recurrence rates reduction. To date, the combined use of these two techniques has been reserved for large or severely inflamed lesions or in case of persistent recurrence. ${ }^{91}$ The safety and effectiveness of this combined method have been emphasized by several studies. Conjunctival autografting in combination with amniotic membrane further reduces recurrence rates, dry eye, and conjunctival inflammation compared with both techniques alone, with better clinical outcomes. ${ }^{92,93}$

In another study, the use of hyperdry amniotic membrane (HD-AM) has been evaluated in comparison with conjunctival 
autograft. ${ }^{94} \mathrm{HD}-\mathrm{AM}$ is made with fresh human amniotic membrane using the hyperdrying method and returns to a layered structure after absorbing water. Okabe et al found that the structures of collagen fibers in the connective tissues were not destroyed in the hyperdry state and were more stable than cryopreserved amniotic membrane. ${ }^{95}$ Allen et al also showed that the biochemical composition of HD-AM, including the number of factors such as epidermal growth factor and TGF- $\beta 1$, was similar to fresh amniotic membrane. ${ }^{96}$ HD-AM is useful in the covering of wide ocular surface defects such as in the case of large or double-headed pterygium. Moreover, management of HD-AM is simple and its use may lead to shorter operating times. It has been reported that recurrence rates in patients receiving HD-AM were significantly lower $(5.06 \%)$ than recurrence rates in conjunctival autografting $(20.97 \% ; P=0.003) .{ }^{94}$

\section{Conjunctival transpositional flap}

Rotational conjunctival flaps have been carried out since 1940 s with different recurrence rates. McCoombes et al reported a $3.2 \%$ recurrence rate, whereas Alpay et al reported a recurrence rate of $33.33 \% .{ }^{97,98}$ Bilge compared conjunctival transpositional flap with conjunctival autografting, evaluating its efficacy, safety, and operating time. Both procedures seemed to provide low recurrence rates, without severe complications. Conjunctival transpositional flap has less torsion effects on tissues and has better cosmetic results in an early and late postoperative period when compared with conjunctival autografting. ${ }^{40}$ This technique can be used as an acceptable method for pterygium surgery, especially in patients with insufficient conjunctiva. ${ }^{99}$ In general, conjunctival transpositional flap is a more challenging surgery than conjunctival autografting, but once mastered, it needs less surgery time when compared with conjunctival autografting. It has been reported that the average surgery duration for both methods can be equal, at around 50 minutes, although it varies among different studies. This was attributed to the difficulty of separating the fibrovascular tissue from a small graft, the smaller size of the graft in relation with the bare sclera, and the need for more sutures to hold the graft in the transpositional method. ${ }^{99}$ Nevertheless, Dadeya et al have observed that the duration of transpositional flap is shorter than the autografting method by 20 minutes, saving a significant amount of surgical time with recurrence rates of $5.58 \%$ for rotational flap and $5.55 \%$ for autografting. ${ }^{100}$ However, Wu et al reported that the recurrence rate after the transpositional flap technique was 35\%. ${ }^{101}$ Jap et al used the rotational flap method when autografting was contraindicated and recorded a recurrent rate of $4 \%$ with an average follow-up

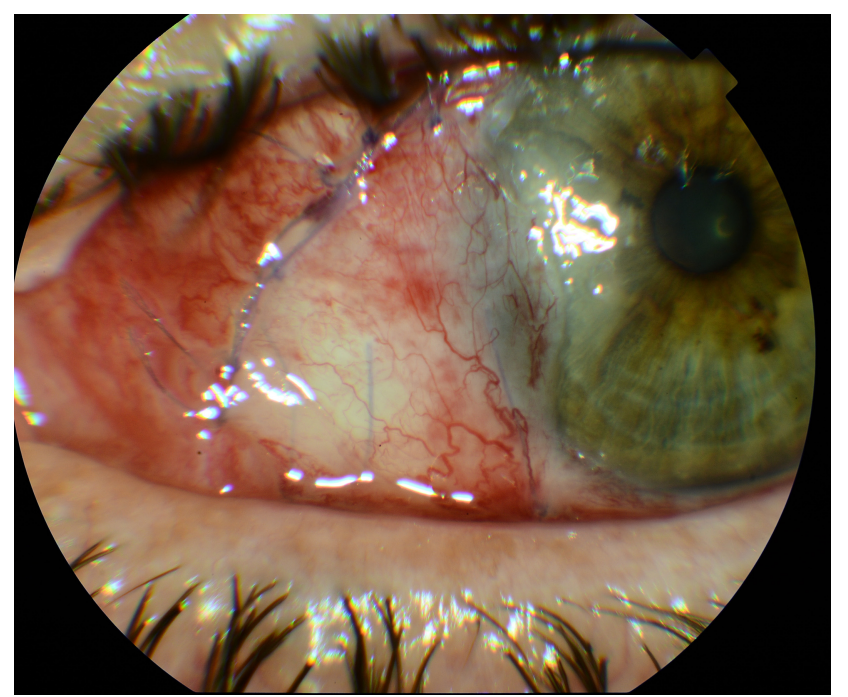

Figure I Postoperative results of a rotational flap, transposed from the inferior conjunctiva, with its vascular pedicle.

of 12 months. ${ }^{102}$ Combination of transpositional conjunctival flap and intraoperative $0.02 \%$ mitomycin $\mathrm{C}$ for 5 minutes provided a recurrence rate of $3 \%$ after 1 year. ${ }^{103}$

All these findings suggest that the transpositional method is similar to conjunctival autografting in terms of recurrence rates, which become significantly lower when intraoperative mitomycin $\mathrm{C}$ is applied, an effective separation of the fibrovascular tissue is performed, and corticosteroid eye drops are used for a longer postoperative time. Given that complications are more frequent in the autografting method, it is better to use this type of surgery when suitable or sufficient conjunctiva for surgery is observed. ${ }^{100}$ Transpositional flap can be safely used when the conjunctival features do not allow conjunctival autografting, with similar recurrence rates and significantly shorter surgical time, even if more studies with a greater number of patients should be performed to get statistically significant results. In addition, conjunctival autografting may need peribulbar anesthesia and tractioning sutures, while it is nearly unnecessary for the transpositional flap technique. ${ }^{40}$ Also, in transpositional graft technique, there is no risk of graft loss and inversion, and the vessel structure is preserved, with better healing process and reduced risk of graft necrosis (Figure 1). However, transpositional flap cannot be taken into consideration in case of large pterygia in which a wider grafting is needed.

\section{Adjuvant therapies Mitomycin C}

Mitomycin C, a substance isolated from Streptomyces caespitosus, is an antibiotic and antineoplastic drug that has been suggested as an adjuvant treatment for pterygium 
surgery in the early 1960s. ${ }^{104}$ Positive outcomes have been reported after an intraoperative application of $0.02 \%$ mitomycin C. In fact, recurrence after mitomycin C use in primary pterygium has been reported to be as low as $7 \%$, while rates after recurrent pterygia were reduced to $9 \% .{ }^{105}$ The association of 5 -minute application of $0.02 \%$ mitomycin $\mathrm{C}$ with bare sclera excision showed to reduce the recurrence rate to $5 \%{ }^{106}$ Moreover, no substantial differences have been observed between postoperative $0.02 \%$ mitomycin $\mathrm{C}$ for 5 days or intraoperative mitomycin $\mathrm{C}$ at different dosages when combined with rotational conjunctival flap. ${ }^{107-112}$ However, it has been shown that conjunctival autografting is associated with significantly lower recurrence rates when compared with excision combined with intraoperative mitomycin C. ${ }^{69,113}$ Nonetheless, two studies reported that the combination of conjunctival autograft with mitomycin $\mathrm{C}$, regardless of the application dosage or method, resulted in significantly lower pterygium recurrence. ${ }^{69,114}$ Moreover, Cardillo et al have reported recurrence rates ranging from $4 \%$ to $6 \%$ with mitomycin C of $0.02 \%$ and $0.04 \%$. Given the similar efficacy, it is recommended to use intraoperative mitomycin $\mathrm{C}$ at the lowest dose. ${ }^{113}$ The most commonly used concentration of mitomycin $\mathrm{C}$ is $0.02 \%(0.2 \mathrm{mg} / \mathrm{mL})$, and the most common application time length is 3 minutes. However, further studies are still needed to determine the optimal concentration and exposure duration. ${ }^{37}$

Several randomized controlled clinical trials compared recurrence rates using various protocols that incorporated intraoperative or postoperative mitomycin $\mathrm{C}$ with different exposure times. Studies regarding primary pterygia alone or combined with recurrent pterygia reported no significant differences in recurrence rates in case of intraoperative or postoperative mitomycin C. ${ }^{115-117}$ Currently, there are no data suggesting whether intraoperative or postoperative mitomycin $\mathrm{C}$ is more efficacious when combined with conjunctival autograft surgery.

Common complications after mitomycin $\mathrm{C}$ application are usually limited to photophobia, postoperative irritation, and ocular discomfort with increased tears, especially if used at low dosages. ${ }^{118}$ However, severe complication can still occur, even after several months from initial treatment. Such adverse events include cataract, symblepharon, anterior uveitis, iritis, scleral thinning or necrosis, corneal opacification and ulceration, prolonged pain, and persistent conjunctival and scleral defects. ${ }^{37}$ High doses and patients' predisposition (eg, dry eye, ichthyosis, acne rosacea) are probably the main reason for mitomycin C-related adverse events. ${ }^{32}$ Hayasaka et al reported late complications featuring calcified plaques at the level of the excision site. When these plaques were removed, scleral thinning was observed, with the need for additional patching grafts in some cases. ${ }^{105}$ Finally, Dougherty et al described a case of severe corneoscleral melting in a patient receiving application of $0.02 \%$ mitomycin $\mathrm{C}$ for 3 minutes followed by closure with a conjunctival rotational flap. ${ }^{119}$

\section{5-Fluorouracil (5-FU)}

5-FU is an antimetabolite first synthesized in 1957 by Dushinsky et al, ${ }^{120}$ with inhibiting effects on the proliferation of corneal epithelial cells and fibroblasts located in conjunctiva and Tenon's capsule. 5-FU has been used as an adjuvant in pterygium surgery with recurrence rates ranging from $11.4 \%$ to $60.0 \%$ after bare sclera technique. ${ }^{121}$ According to a series of 125 eyes receiving intraoperative 5-FU (at a dose of $25 \mathrm{mg} / \mathrm{mL}$ ), pterygia recurred in $36 \%{ }^{122}$ Higher doses of 5 -FU $(50 \mathrm{mg} / \mathrm{mL})$ lead to a recurrence decrease at around $11 \%$, with no statistically significant advantages when compared with conjunctival autografting alone. ${ }^{121}$ Although there is little evidence in the literature to encourage a routinely 5-FU use for this surgery, this adjuvant treatment appears to maintain a role in treating recurrent pterygia. ${ }^{123-125}$ In fact, Prabhasawat et al reported recurrence rates of $7.7 \%$ when 5 -FU was used for impending recurrent pterygium. ${ }^{73}$

Only minor or temporary adverse events have been reported after 5-FU use in pterygium surgery. ${ }^{32}$ However, a case of cicatricial ectropion after topical 5-FU and a case of punctal-canalicular stenosis after systemic administration have been described. ${ }^{126,127}$ Adverse events after 5-FU application are more commonly reported in its employment for glaucoma surgery, including persistent epithelial defects, spontaneous bleb rupture, and bacterial ulcerations. However, 5-FU doses used in these cases are five to ten times higher than those suggested for pterygium surgery (10/20 mg). Because toxicity is still possible even at lower doses, the use of 5-FU is not recommended in patients with a history of corneal diseases. ${ }^{128,129}$

\section{Radiation}

The use of radiotherapy as an adjuvant treatment for pterygium has been described since $1912 .{ }^{130}$ Since 1950, the radioactive material used for pterygium treatment through irradiation has been strontium- $90\left({ }^{88} \mathrm{Sr}\right)$. This element seems suitable for the treatment of ocular surface diseases because it emits $\beta$-rays whose energy decrease rapidly as they 
penetrate in the underlying tissues (dropping off to $41 \%$ at $1 \mathrm{~mm}$ depth, $19 \%$ at $2 \mathrm{~mm}, 9 \%$ at $3 \mathrm{~mm}$, and $1 \%$ at $5 \mathrm{~mm}$ ), preventing damage to deeper structures. ${ }^{131}$ Currently, there exists a wide variety of dose fractionation schemes, ranging from 20 Grays (Gy) in single fraction in the immediate postoperative period to $60 \mathrm{~Gy}$ in 6 weekly fractions or 24-30 Gy in 3 weekly fractions. ${ }^{132-134}$ Positive outcomes were also proven in case of immediate postoperative radiotherapy of 25 Gy in a single fraction, after excision with bare sclera technique (6.82\% recurrence rate). ${ }^{132}$ Brenner and Merriam implied that fractionation rather than single dose gives an increased therapeutic ratio between absence of recurrences and late side effects. ${ }^{135}$ Nonetheless, as supported by the North Florida Pterygium Study Group and other authors, radiotherapy gives best results when started within 24 hours of complete excision. ${ }^{134}$

Adverse events following radiotherapy include ocular burning, foreign body sensation, photophobia, conjunctival scarring, corneal opacities, cataracts, grauloma formation, and scleral atrophy. Severe late adverse events that may occur years after surgery are represented by bacterial corneoscleritis, scleral ulceration, and symblepharon. ${ }^{136-139}$ However, as of today, there is still no definitive consensus between single dose vs total dose. Moreover, the most effective time of exposure needs to be further assessed.

\section{Antivascular endothelial growth factor (anti-VEGF)}

Khalfaoui et al found that VEGF is overexpressed in recurrent pterygium and suggested an important role of angiogenesis and neovascularization in pterygium recurrence. ${ }^{140}$ The first study to report a case of subconjunctival injection of bevacizumab in primary pterygium was conducted by Teng et al. A subconjunctival injection of bevacizumab was performed into an inflamed pterygium at the level of the limbus, with rapid regression of neovascularization signs, and inflammation, although the effects were only short term. ${ }^{141}$ This transient effect is probably related to a limited bioavailability in a framework of continuous VEGF expression. An intensive high-dose anti-VEGF therapy with ziv-aflibercept can lead to resolution of inflammation and new vessel growth in inflamed pterygia, but current evidence does not support intralesional VEGF antagonists in the surgical management of noninflamed pterygia. ${ }^{142}$

Shenasi et al, in their study evaluating subconjunctival bevacizumab injection immediately after pterygium excision, found that the recurrence rate was lower in patients receiving the adjuvant treatment. ${ }^{143}$ Razeghinejad and Banifatemi reported that subconjunctival bevacizumab injected immediately after rotational conjunctival flap and 4 days after surgery was efficient in preventing pterygia recurrence, even if the difference with the control group failed to reach a statistically significant level. ${ }^{144}$ Shahin et al found that a subconjunctival injection of $1.25 \mathrm{mg} / 0.05 \mathrm{~mL}$ of bevacizumab at the end of the surgery did not result in a statistically significant difference in the recurrence rates. ${ }^{145}$

Even if a single postoperative administration of subconjunctival bevacizumab is well tolerated and decreases the number and caliber of corneal blood vessels, this favorable effect is incomplete and temporary. ${ }^{146}$ Repeated injections in the first year after surgery may help prevent the high recurrence rate; however, side effects of multiple or increased doses must be addressed, and further evaluations are needed to be prove bevacizumab as a good adjuvant. In fact, considering its high costs, bevacizumab has not presented fully satisfactory results. In a previous study, we evaluated the application of subconjunctival bevacizumab injections at the dosage of $2.5 \mathrm{mg} / 0.1 \mathrm{~mL}$, before and after surgical pterygium excision with bare sclera technique ( 1 week before and 15 days after surgery). It was the only study with this particular injection timing, proving that this repeated modality may be useful in preventing lesion recurrence after bare scleral procedures and that it can lead to more satisfactory benefit-cost ratio. Furthermore, bevacizumab subconjunctival administration is well tolerated and may represent a safer alternative when compared with other surgical techniques and adjunctive drugs. ${ }^{147}$ Finally, a recent meta-analysis by Sun et al confirmed a statistically significant effect of bevacizumab in preventing primary pterygium recurrence, without significant increase in adverse reactions. ${ }^{148}$

Preoperative subpterygium-combined injection of bevacizumab and mitomycin $\mathrm{C}$ is safe and effective in reducing the postoperative recurrence of primary pterygium, especially if applied 1 month before surgery. A study evaluating histological and immunohistological changes reported a decreased fibrovascular activity and degeneration of the extracellular matrix and nerve axons. Moreover, combination of mitomycin $\mathrm{C}$ and bevacizumab led to a significant decrease in CD31-positive cells, with low levels of inflammatory cellular infiltration, fibroblasts, and goblet cells, in association with a significant increase in collagen fibers. This could be secondary to the combined anti-VEGF action of bevacizumab and the antifibroblastic activity of mitomycin C. ${ }^{149}$ 


\section{Topical cyclosporine A (CsA)}

CsA is an anti-inflammatory and immunosuppressive drug, which can help to significantly reduce pterygium recurrence when used in the postoperative time. ${ }^{150,151}$ Ibáñez et al used adjuvant $\mathrm{CsA}$ at a $0.10 \%$ concentration, which differed from other studies that used CsA at a $0.05 \%$ concentration with no significant differences. ${ }^{152}$ Moreover, adjuvant use of CsA in the treatment of pterygium was superior when compared with patients receiving only excisional surgery. ${ }^{151,153,154}$

In the study by Aydin et al, only one case of recurrence occurred in the CsA group after conjunctival autografting, with a recurrence rate five times lower than the control group. ${ }^{153}$ However, because of the small sample size, the study failed to reach statistical significance. Similarly, in the study by Ibáñez et al, the recurrence rate was two times higher in the control group than in the CsA group. ${ }^{152}$

It is possible that surgical techniques as conjunctival autograft or conjunctival flap rotation could themselves decrease the incidence of pterygium recurrence, regardless of the adjuvant use of CsA. Thus, additional studies with larger sample sizes and longer follow-up are needed in order to draw more definitive conclusions. Possible mechanisms explaining the adjuvant use of CsA are related to the higher expression of IL-6 and IL-8 in pterygia epithelium leading to angiogenesis increase through VEGF. ${ }^{16,155,156}$
Similarly, T-lymphocyte-mediated cellular immunity seems to play a key role in pterygium pathogenesis. Moreover, Lin et al showed that lymphatic microvessel density was a predictive factor for pterygium recurrence. ${ }^{157,158} \mathrm{CsA}$ can selectively suppress T-lymphocytes, which can produce inflammatory cytokines and mediators. ${ }^{159}$ In addition, CsA can also inhibit the angiogenesis triggered by VEGF. Therefore, inhibition of both these pathways provided by CsA might be an effective method for preventing postoperative recurrence.

Adjuvant use of CsA is relatively safe in comparison with other adjuvant treatment, except in the case of preexisting scleral thinning. Nevertheless, CsA administration can still be considered a well-tolerated adjuvant substance for pterygium treatment. However, the current limited evidence can only suggest that CsA is useful to significantly reduce recurrence rates when compared with simple pterygium excision, whereas the adjuvant use of CsA may not reduce the risk of pterygium recurrence when combined with conjunctival autografting or rotational flap. ${ }^{151}$

\section{Clinical perspectives}

Key features of surgical techniques and adjuvant treatments are summarized in Tables 1 and 2, respectively. Meticulous excision of pterygium stromal tissue is the first step that must be performed to achieve favorable surgical outcomes

Table I Summary of main characteristics of different surgical techniques for pterygium excision

\begin{tabular}{|c|c|c|}
\hline Technique & Advantages & Drawbacks \\
\hline Bare sclera technique & $\begin{array}{l}\text { - Easy to perform } \\
\text { - Short surgical time }\end{array}$ & $\begin{array}{l}\text { - High recurrence rates } \\
\text { - Possible discomfort and pain (related to pterygium } \\
\text { extension) }\end{array}$ \\
\hline Conjunctival autograft & $\begin{array}{l}\text { - Low recurrence rates } \\
\text { - Easy to perform (in comparison with transpositional flap) } \\
\text { - Good cosmetic results }\end{array}$ & $\begin{array}{l}\text { - Long surgical time (especially in suture-assisted fixation) } \\
\text { - Possible discomfort and pain (especially in suture-assisted } \\
\text { fixation) } \\
\text { - Cannot be applied in patients with insufficient conjunctiva } \\
\text { - Risk of graft loss/displacement (sutureless fixation) } \\
\text { - Possible conjunctival cicatrization } \\
\text { - Difficulty in covering of large defects }\end{array}$ \\
\hline Amniotic membrane & $\begin{array}{l}\text { - Easier to perform (in comparison with conjunctival } \\
\text { autografting) } \\
\text { - Useful to cover large defects } \\
\text { - Conjunctival sparing } \\
\text { - Short surgical time } \\
\text { - Can be applied in patients with insufficient conjunctiva }\end{array}$ & $\begin{array}{l}\text { - Higher recurrence rates (in comparison with conjunctival } \\
\text { autografting) } \\
\text { - Risk of graft loss/displacement (sutureless fixation) } \\
\text { - Possible discomfort and pain (suture-assisted fixation) }\end{array}$ \\
\hline $\begin{array}{l}\text { Conjunctival } \\
\text { transpositional flap }\end{array}$ & $\begin{array}{l}\text { - Low recurrence rates } \\
\text { - Low risk of graft loss or necrosis } \\
\text { - Better graft healing due to vascular pedicle } \\
\text { - Short surgical time } \\
\text { - Better postoperative cosmetic results (in comparison } \\
\text { with conjunctival autografting) } \\
\text { - Can be applied in patients with insufficient conjunctiva }\end{array}$ & $\begin{array}{l}\text { - Challenging technique (in comparison with conjunctival } \\
\text { autografting) } \\
\text { - Difficulty in covering of large defects } \\
\text { - Possible discomfort and pain (suture-assisted fixation) }\end{array}$ \\
\hline
\end{tabular}


Table 2 Summary of characteristics of different adjuvant treatments in pterygium surgery

\begin{tabular}{|c|c|c|}
\hline Adjuvant treatment & Advantages & Drawbacks \\
\hline Topical mitomycin C & - Significant recurrence rate reduction & $\begin{array}{l}\text { - Low tolerability } \\
\text { - Risk of severe toxicity (eg, corneoscleral necrosis) } \\
\text { - Cannot be applied in case of thin sclera or preexisting corneal disease }\end{array}$ \\
\hline Radiation & - Significant recurrence rate reduction & $\begin{array}{l}\text { - No unified fractioning schemes } \\
\text { - Corneoscleral toxicity } \\
\text { - Possible late-onset toxicity (eg, infections and scleral ulceration) }\end{array}$ \\
\hline Subconjunctival anti-VEGF & $\begin{array}{l}\text { - Significant recurrence rate reduction } \\
\text { - Good tolerability } \\
\text { - Possible repeated injections }\end{array}$ & $\begin{array}{l}\text { - High costs } \\
\text { - Transient effect } \\
\text { - No unified injection timing }\end{array}$ \\
\hline Topical 5-fluorouracil & $\begin{array}{l}\text { - Minor toxicity in pterygium surgery } \\
\text { - Useful in recurrent pterygium }\end{array}$ & $\begin{array}{l}\text { - Controversial efficacy } \\
\text { - Limited evidence for pterygium surgery } \\
\text { - No significant recurrence reduction when compared with simple surgery } \\
\text { with conjunctival graft } \\
\text { - Cannot be applied in case of thin sclera or preexisting corneal disease }\end{array}$ \\
\hline Topical cyclosporine A & $\begin{array}{l}\text { - Mechanism of action on multiple } \\
\text { pathological processes } \\
\text { - Good tolerability }\end{array}$ & $\begin{array}{l}\text { - High costs } \\
\text { - Limited evidence for pterygium surgery } \\
\text { - Cannot be applied in case of thin sclera }\end{array}$ \\
\hline
\end{tabular}

Abbreviation: VEGF, vascular endothelial growth factor.

because the presence of fibroblasts is probably related to postoperative recurrence. However, this is not sufficient to prevent recurrence events. In order to minimize the risk of postoperative recurrence, it is necessary to perform a complete fibroblast ablation at the level of the surgical wound through accurate removal of subconjunctival fibrovascular tissue. In addition, to promote rapid epithelialization, the bare scleral area should always be covered using a conjunctival rotational flap, amniotic membrane, or a conjunctival autograft. In fact, bare sclera technique is characterized by high recurrence rates ranging from $33 \%$ to $88 \%{ }^{35}$

Moreover, a residual large defect after excision induces severe pain leading to wound hypertrophy and higher risk of recurrence, according to our and other authors' experience. ${ }^{160}$ It has been reported that neuropeptides involved in pain sensitivity, such as substance $P$, stimulates chemotaxis of injury-inducible stromal-like cells from the bone marrow to the site of injury. ${ }^{161}$ For these reasons, techniques leading to high perioperative pain should be avoided if possible. In addition, epithelial wound healing should be promoted and accelerated in order to prevent prolonged stromal overgrowth that may occur when the overlying epithelium (which provides inhibition of stromal proliferation through contact) is absent. Postoperative pain management is crucial in reducing the risk of recurrence and should be performed through either bandage patching or therapeutic contact lenses (TCLs). Despite the fact that bandage patching may interfere with visual field (thus contraindicated in case of monocular vision), it has been reported that this method procures better pain relief and sleep quality in the first 24 hours after pterygium excision when compared with TCLs. ${ }^{162}$ For this reason, tight bandage patching should be preferred over contact lenses if no contraindications to ocular occlusion are observed. TCLs can still be applied in case of persistent pain or corneal defects after the first postoperative day. Anyways, both methods proved to be efficient in controlling postoperative pain and favoring corneal reepithelization. ${ }^{163-165}$ Anti-inflammatory eye drops, such as corticosteroids and NSAID, and artificial tears represent commonly used molecules for controlling pain and favoring corneal healing after pterygium surgery. It has been observed that nepafenac $0.1 \%$ eye drops administered thrice a day for 3 days (in association with postoperative therapy with topical ciprofloxacin, fluorometholone, and artificial tears) provided a significant pain reduction when compared with placebo after pterygium excision with autologous conjunctival graft. ${ }^{166}$ An alternative treatment for rapid corneal epithelial healing and pain reduction after pterygium surgery is represented by autologous serum eye drops, which led to favorable results, as reported in a study by Sul et al. ${ }^{167}$ However, the evidence of autologous serum eye drops in pterygium surgery is currently limited. In addition, systemic analgesic drugs should be considered in the management of postoperative pain, especially if intense or persistent despite adequate topical treatment.

Immediate coverage of large defects with conjunctival autograft, rotational flap, or amniotic membrane is recommended. Healthy conjunctival tissue should be preserved if possible, especially in case of patients who may require surgery for glaucoma. As of today, conjunctival autografting is considered the most effective technique for pterygium treatment and proved to provide better outcomes with respect to amniotic membrane transplantation. 
Moreover, conjunctival autografting operating time can be importantly reduced, thanks to sutureless fixating techniques. According to the literature, amniotic membrane transplantation can still be reserved in case of unhealthy or insufficient conjunctival tissue. In our experience, in case of recurrence after conjunctival rotational flap technique, it is advisable to apply a conjunctival or amniotic membrane patch associated with long-lasting treatment with corticosteroid eye drops in order to reduce postsurgical flogosis. Superior or inferior conjunctival tissue did not prove to provide better results when compared with each other.

Several adjuvant options to reduce the proliferative activity of stromal fibroblasts during the postoperative recovery phase have been proposed. Fonseca et al suggested that bare sclera excision $+\beta$ therapy 25 Gy in single dose, bare sclera technique + mitomycin $\mathrm{C} 0.02 \%$, and conjunctival autograft + cyclosporine $0.05 \%$ eye drops are the best strategies to prevent recurrence after pterygium surgery. ${ }^{168}$ However, randomized clinical trials to evaluate efficacy of adjuvant therapies for pterygium are relatively few and with small sample size. In the light of the current evidence, mitomycin $C$, $\beta$-radiotherapy, and bevacizumab were significantly more effective than placebo for reducing recurrence following pterygium excision, with mitomycin $\mathrm{C}$ having the higher efficacy. ${ }^{18,169-173}$ Although bevacizumab ranked higher than $\beta$-radiotherapy for its efficacy, this difference was not statistically significant. However, bevacizumab is associated with less severe adverse events when compared with mitomycin $\mathrm{C}$ or radiation therapy; hence, repeated injections (which are needed to avoid the transient effects of anti-VEGF drugs) are safe and possible. Topical postoperative CsA gives appealing hopes for adjuvant therapy, but current evidence is still poor to evaluate its safety and efficacy in pterygium surgery. 5-FU did not show a statistically significant efficacy in preventing postoperative recurrence.

As of today, optimal dose, duration, and administration protocol for adjuvant treatments are still not fully defined. With regard to radiotherapy, the commonly used dose is 25 Gy with bare sclera technique, which is decreased to 10 Gy when combined with conjunctival autografting. ${ }^{174}$ Administration and dose of 5-FU were consistent among trials; however, duration of administration varied from 3 to 5 minutes. Bevacizumab dosage ranged from 1.25 to $7.5 \mathrm{mg}$ in different studies, and its administration approach can be manifold among different studies. ${ }^{174}$ The most common way of bevacizumab administration is subconjunctival at the time of surgery, associated with pre- or postoperative injections. We have reported that recurrence after bare sclera technique was reduced with both pre- and postoperative subconjunctival injections of bevacizumab and that this administration protocol is safe and feasible. ${ }^{147}$ Administration protocols of mitomycin $\mathrm{C}$ are inconsistent as well, with different dose, durations, and approaches. Adjuvant treatments still need standardization regarding dosage, time, and ways of administration because no definitive recommendations or guidelines are being produced. Another issue that must be taken into consideration is the side effects associated with adjuvant therapies, which alter the benefit-risk ratio. Therefore, the detection of patients who will benefit from adjuvant treatments is most relevant in the preoperative setting and risk factors for recurrence must be addressed. Reports showed that $50 \%$ of recurrences might occur within 4 months and 97\% might occur within 12 months. Thus, follow-up of at least 1 year is appropriate.

Some studies reported that age, race, morphology, and increased inflammation after surgery are related to a greater risk of recurrence. ${ }^{34,175-180}$ Therefore, accurate collection of patients' clinical information is fundamental to better predict the recurrence risk. However, actual assessment tools for routine clinical practice have not yet been developed for this disease. In order to find out reliable strategies for pterygium treatment, better understanding of molecular mechanisms involved in its pathogenesis is necessary. Several molecular pathways have been evaluated, and different biomarkers have been proposed. It is known that pterygium features altered proliferation of basal epithelial cells and neovascularization, with invasion of corneal epithelium. UV radiation, together with epigenetic aberrations, is strongly related to pterygium development and progression. However, because viral infections have been reported as a potential factor for pterygium pathogenesis, deeper understanding of their role may be crucial in the detection of subjects at risk of recurrence. ${ }^{14}$ Pterygium fibrovascular redness has been proposed as a novel parameter for pterygium grading. In fact, an automated redness analysis proposed by Hilmi et al showed a significant correlation with visual acuity and contrast sensitivity reduction, suggesting that pterygium morphology must be considered for the evaluation of clinical decisions and postoperative recurrence prediction. ${ }^{181}$

Several growth factors and cytokines involved in angiogenesis and lymphangiogenesis, and many different proteinases as well, are related to pterygium development and persistence. Another promising field of research for pterygium pathogenesis is represented by modifications of cholesterol metabolism, even if further studies are needed. ${ }^{14}$ Transition from epithelial to mesenchymal cells in pterygium has suggested that this pathology shares molecular basis with 
tumors. In fact, molecular pathways involved in increased proliferative activity (Ki-67, proliferation cell nuclear antigen, and erythropoietin), inhibition of apoptosis (Bcl-2 and p53), and malignancy (Hsp90) are overexpressed in the epithelial pterygium cells when compared with normal conjunctiva. ${ }^{182-184}$ In addition, abnormal methylation of genes related to extracellular matrix modulation 2, tumor suppression (p16), and cell adhesion (TGM-2 and CD24) has been correlated to pterygium invasiveness and uncontrolled proliferation. ${ }^{185,186}$ Oxidative stress caused by UV radiation may be responsible for these abnormal methylation patterns, although not confirmed yet.

Several studies have demonstrated a significant improvement in induced astigmatism after pterygium surgery. ${ }^{187-192}$ Kheirkhah et al evaluated corneal astigmatism with a Scheimpflug imaging system, concluding that pterygium surgery was associated with significant changes in curvature of front and back corneal surfaces, especially in case of advanced pterygia. ${ }^{193}$ However, it has been observed that no surgical technique or fixating method was superior in terms of postoperative astigmatism changes. ${ }^{194}$ Pterygium, especially with large size, is correlated with optical aberrations, and several studies have demonstrated that surgery with conjunctival autograft leads to significant improvements in corneal wave front aberrations (including high-order aberrations, trefoil, and coma), visual acuity, refractive errors, and different corneal topographic values. ${ }^{195-198}$ However, there are no comparison studies regarding optical aberration modifications after adjuvant techniques different from conjunctival autografting.

\section{Conclusion}

Bare sclera technique is associated with worst outcomes, with higher recurrence risk. Pterygium surgery cannot disregard wound coverage with conjunctival autografting or rotational flap combined with adjuvant treatments. According to our experience, the conjunctival rotational flap technique is associated with low recurrence rates and the vascular pedicle prevents graft displacement and necrosis. Despite their high cost, subconjunctival anti-VEGF injections (which can be performed before and after surgery) are a safe and efficient adjuvant treatment. However, future treatment strategies will probably target multiple pathways, taking into consideration the novel findings related to pathogenesis. Additional studies should consider recurrence rates in accordance with geographic regions and long-term follow-ups to improve the understanding of pterygium treatment and develop universal guidelines. Great importance should be dedicated to the identification of novel molecular biomarkers of recurrence, in order to perform a customized surgical treatment for each patient and achieve maximal reduction of postoperative recurrence.

\section{Disclosure}

The authors report no conflicts of interest in this work.

\section{References}

1. Dushku N, John MK, Schultz GS, Reid TW. Pterygia pathogenesis: corneal invasion by matrix metalloproteinase expressing altered limbal epithelial basal cells. Arch Ophthalmol. 2001;119(5):695-706.

2. Aspiotis M, Tsanou E, Gorezis S, et al. Angiogenesis in pterygium: study of microvessel density, vascular endothelial growth factor, and thrombospondin-1. Eye. 2007;21(8):1095-1101.

3. Kase S, Osaki M, Jin XH, et al. Increased expression of erythropoietin receptor in human pterygial tissues. Int J Mol Med. 2007;20(5): 699-702.

4. Tsai YY, Chiang CC, Yeh KT, Lee H, Cheng YW. Effect of TIMP-1 and MMP in pterygium invasion. Invest Ophthalmol Vis Sci. 2010;51(7): $3462-3467$.

5. Liang K, Jiang Z, Ding BQ, Cheng P, Huang DK, Tao LM. Expression of cell proliferation and apoptosis biomarkers in pterygia and normal conjunctiva. Mol Vis. 2011;17:1687-1693.

6. Coroneo MT. Pterygium as an early indicator of ultraviolet insolation: a hypothesis. Br J Ophthalmol. 1993;77(11):734-739.

7. Hilgers JH. Pterygium: its incidence, heredity and etiology. Am J Ophthalmol. 1960;50(4):635-644.

8. Marchetti C, Sidahmed-Adrar N, Collin F, Jore D, Gardès-Albert M, Bonnefont-Rousselot D. Melatonin protects PLPC liposomes and LDL towards radical-induced oxidation. J Pineal Res. 2011;51(3): 286-296.

9. Kau HC, Tsai CC, Lee CF, et al. Increased oxidative DNA damage, 8-hydroxydeoxy-guanosine, in human pterygium. Eye. 2006;20(7): 826-831.

10. Balci M, Sahin S, Mutlu FM, Yağci R, Karanci P, Yildiz M. Investigation of oxidative stress in pterygium tissue. Mol Vis. 2011;17:443-447.

11. Reid TW, Dushku N. Does human papillomavirus cause pterygium? Br J Ophthalmol. 2003;87(7):806-808.

12. Di Girolamo N. Association of human papilloma virus with pterygia and ocular-surface squamous neoplasia. Eye. 2012;26(2):202-211.

13. Detorakis ET, Drakonaki EE, Spandidos DA. Molecular genetic alterations and viral presence in ophthalmic pterygium. Int J Mol Med. 2000; 6(1):35-41.

14. Cárdenas-Cantú E, Zavala J, Valenzuela J, Valdez-García JE. Molecular basis of pterygium development. Semin Ophthalmol. 2016;31(6): $567-583$.

15. Di Girolamo N, Chui J, Coroneo MT, Wakefield D. Pathogenesis of pterygia: role of cytokines, growth factors, and matrix metalloproteinases. Prog Retin Eye Res. 2004;23(2):195-228.

16. Di Girolamo N, Kumar RK, Coroneo MT, Wakefield D. UVB-mediated induction of interleukin- 6 and -8 in pterygia and cultured human pterygium epithelial cells. Invest Ophthalmol Vis Sci. 2002;43(11): 3430-3437.

17. Siak JJK, Ng SL, Seet LF, Beuerman RW, Tong L. The nuclear-factor $\mathrm{KB}$ pathway is activated in pterygium. Invest Ophthalmol Vis Sci. 2011; 52(1):230-236.

18. Pinkerton OD, Hokama Y, Shigemura LA. Immunologic basis for the pathogenesis of pterygium. Am J Ophthalmol. 1984;98(2):225-228.

19. Ling S, Liang L, Lin H, Li W, Xu J. Increasing lymphatic microvessel density in primary pterygia. Arch Ophthalmol. 2012;130(6): 735-742.

20. Jin J, Guan M, Sima J, et al. Decreased pigment epithelium-derived factor and increased vascular endothelial growth factor levels in pterygia. Cornea. 2003;22(5):473-477. 
21. Riau AK, Wong TT, Lan W, et al. Aberrant DNA methylation of matrix remodeling and cell adhesion related genes in pterygium. PLoS One. 2011;6(2):e14687.

22. Kria L, Ohira A, Amemiya T. Immunohistochemical localization of basic fibroblast growth factor, platelet derived growth factor, transforming growth factor-beta and tumor necrosis factor-alpha in the pterygium. Acta Histochem. 1996;98(2):195-201.

23. Hanahan D, Folkman J. Patterns and emerging mechanisms of the angiogenic switch during tumorigenesis. Cell. 1996;86(3):353-364.

24. Park CY, Choi JS, Lee SJ, Hwang SW, Kim EJ, Chuck RS. Cyclooxygenase-2-expressing macrophages in human pterygium co-express vascular endothelial growth factor. Mol Vis. 2011;17:3468-3480.

25. Solomon A, Grueterich M, Li DQ, Meller D, Lee SB, Tseng SC. Overexpression of insulin-like growth factor-binding protein-2 in pterygium body fibroblasts. Invest Ophthalmol Vis Sci. 2003;44(2):573-580.

26. Ye J, Song YS, Kang SH, Yao K, Kim JC. Involvement of bone marrowderived stem and progenitor cells in the pathogenesis of pterygium. Eye. 2004;18(8):839-843.

27. Song YS, Ryu YH, Choi SR, Kim JC. The involvement of adult stem cells originated from bone marrow in the pathogenesis of pterygia. Yonsei Med J. 2005;46(5):687-692.

28. Peiretti E, Dessì S, Mulas C, et al. Modulation of cholesterol homeostasis by antiproliferative drugs in human pterygium fibroblasts. Invest Ophthalmol Vis Sci. 2007;48(8):3450-3458.

29. Anguria P, Kitinya J, Ntuli S, Carmichael T. The role of heredity in pterygium development. Int J Ophthalmol. 2014;7(3):563-573.

30. Mohammed I. Treatment of pterygium. Ann Afr Med. 2011;10(3): 197-203.

31. Fernandes M, Sangwan VS, Bansal AK, et al. Outcome of pterygium surgery: analysis over 14 years. Eye. 2005;19(11):1182-1190.

32. Hovanesian JA, Starr CE, Vroman DT; The ASCRS Cornea Clinical Committee. Surgical techniques and adjuvants for the management of primary and recurrent pterygia. J Cataract Refract Surg. 2017;43(3): 405-419.

33. Rohrbach IM, Starc S, Knorr M. Vorhersage von Pterygiumrezidiven Aufgrund Morphologischer und Immunhistologischer Parameter [Predicting recurrent pterygium based on morphologic and immunohistologic parameters]. Ophthalmologe. 1995;92(4): 463-468.

34. Kim KW, Kim JC. Current approaches and future directions in the management of pterygium. Int J Ophthalmol. 2018;11(5):709-711.

35. Tan DT, Chee SP, Dear KB, Lim AS. Effect of pterygium morphology on pterygium recurrence in a controlled trial comparing conjunctival autografting with bare sclera excision. Arch Ophthalmol. 1997; 115(10):1235-1240.

36. Kim KW, Park SH, Kim JC. Fibroblast biology in pterygia. Exp Eye Res. 2016;142:32-39.

37. Kaufman SC, Jacobs DS, Lee WB, Deng SX, Rosenblatt MI, Shtein RM. Options and adjuvants in surgery for pterygium: a report by the American Academy of Ophthalmology. Ophthalmology. 2013;120(1):201-208.

38. Sánchez-Thorin JC, Rocha G, Yelin JB. Meta-analysis on the recurrence rates after bare sclera resection with and without mitomycin $\mathrm{C}$ use and conjunctival autograft placement in surgery for primary pterygium. Br J Ophthalmol. 1998;82(6):661-665.

39. Kenyon KR, Wagoner MD, Hettinger ME. Conjunctival autograft transplantation for advanced and recurrent pterygium. Ophthalmology. 1985;92(11):1461-1470.

40. Bilge AD. Comparison of conjunctival autograft and conjunctival transposition flap techniques in primary pterygium surgery. Saudi $J$ Ophthalmol. 2018;32(2):110-113.

41. Koranyi G, Seregard S, Kopp ED. The cut-and-paste method for primary pterygium surgery: long-term follow-up. Acta Ophthalmol Scand. 2005;83(3):298-301.

42. Ma DH, See LC, Liau SB, Tsai RJ. Amniotic membrane graft for primary pterygium: comparison with conjunctival autograft and topical mitomycin C treatment. Br J Ophthalmol. 2000;84(9):973-978.
43. Al Fayez MF. Limbal versus conjunctival autograft transplantation for advanced and recurrent pterygium. Ophthalmology. 2002;109(9): $1752-1755$.

44. Cornelius CR. Recurrence rate and complications of pterygium extended removal followed by extended conjunctival transplant. Cornea. 2017; 36(1):101-103

45. Kumar S, Singh R. Pterygium excision and conjunctival autograft: a comparative study of techniques. Oman J Ophthalmol. 2018;11(2):124-128.

46. Cohen RA, McDonald MB. Fixation of conjunctival autografts with an organic tissue adhesive. Arch Ophthalmol. 1993;111(9):1167-1168.

47. Koranyi G, Seregard S, Kopp ED. Cut and paste: a no suture, small incision approach to pterygium surgery. Br J Ophthalmol. 2004;88(7):911-914.

48. Romano V, Cruciani M, Conti L, Fontana L. Fibrin glue versus sutures for conjunctival autografting in primary pterygium surgery. Cochrane Database Syst Rev. 2016;12(4):CD011308.

49. Ratnalingam V, Eu AL, Ng GL, Taharin R, John E. Fibrin adhesive is better than sutures in pterygium surgery. Cornea. 2010;29(5):485-489.

50. Uy HS, Reyes JM, Flores JD, Lim-Bon-Siong R. Comparison of fibrin glue and sutures for attaching conjunctival autografts after pterygium excision. Ophthalmology. 2005;112(4):667-671.

51. Celik T. In situ blood coagulum versus sutures for autograft fixation after pterygium excision. Curr Eye Res. 2018;43(8):977-980.

52. Kurian A, Reghunadhan I, Nair KG. Autologous blood versus fibrin glue for conjunctival autograft adherence in sutureless pterygium surgery: a randomised controlled trial. Br J Ophthalmol. 2015;99(4):464-470.

53. Choudhury S, Dutta J, Mukhopadhyay S, et al. Comparison of autologous in situ blood coagulum versus sutures for conjunctival autografting after pterygium excision. Int Ophthalmol. 2014;34(1):41-48.

54. Natung T, Keditsu A, Shullai W, Goswami PK, Sutureless GPK. Sutureless, glue-less conjunctival autograft versus conjunctival autograft with sutures for primary, advanced pterygia: an interventional pilot study. J Clin Diagn Res. 2017;11(8):NC04-NC07.

55. Lešin M, Paradžik M, Marin Lovrić J, et al. Cauterisation versus fibrin glue for conjunctival autografting in primary pterygium surgery (CAGE CUP): study protocol of a randomised controlled trial. BMJ Open. 2018;8(6):e020714.

56. Küçükerdönmez C, Akova YA, Altinörs DD. Comparison of conjunctival autograft with amniotic membrane transplantation for pterygium surgery: surgical and cosmetic outcome. Cornea. 2007;26(4):407-413.

57. Vrabec MP, Weisenthal RW, Elsing SH. Subconjunctival fibrosis after conjunctival autograft. Cornea. 1993;12(2):181-183.

58. Mullins JB, Holds JB, Branham GH, Thomas JR. Complications of the transconjunctival approach. A review of 400 cases. Arch Otolaryngol Head Neck Surg. 1997;123(4):385-388.

59. Ferry AP. Pyogenic granulomas of the eye and ocular adnexa: a study of 100 cases. Trans Am Ophthalmol Soc. 1989;87:327-343.

60. Zhang Z, Yang Z, Pan Q, Chen P, Guo L. Clinicopathologic characteristics and the surgical outcome of conjunctival granulomas after pterygium surgery. Cornea. 2018;37(8):1008-1012.

61. Kapadia SB, Heffner DK. Pitfalls in the histopathologic diagnosis of pyogenic granuloma. Eur Arch Otorhinolaryngol. 1992;249(4):195-200.

62. Lindquist TP, Lee WB. Mitomycin C-associated scleral stromalysis after pterygium surgery. Cornea. 2015;34(4):398-401.

63. Zloto O, Rosen N, Leshno A, Rosner M. Very long term success of pterygium surgery with conjunctival graft. Cont Lens Anterior Eye. 2017;40(4):267-269.

64. Koç F, Demirbay P, Teke MY. Primer ve rekürren pterygiumda konjonktival otogreftleme. T Oft Gaz. 2002:583-588.

65. Syam PP, Eleftheriadis H, Liu CS. Inferior conjunctival autograft for primary pterygia. Ophthalmology. 2003;110(4):806-810.

66. Paracha Q, Ayoob M, Dawood Z, Mirza SA. Recurrence rate with use of intraoperative mitomycin $\mathrm{C}$ versus conjunctival autograft following pterygium excision. PakJ Med Sci. 2014;30(6):1243-1246.

67. Keklikci U, Celik Y, Cakmak SS, Unlu MK, Bilek B. Conjunctival-limbal autograft, amniotic membrane transplantation, and intraoperative mitomycin C for primary pterygium. Ann Ophthalmol. 2007;39(4):296-301. 
68. Tananuvat N, Martin T. The results of amniotic membrane transplantation for primary pterygium compared with conjunctival autograft. Cornea. 2004;23(5):458-463.

69. Frucht-Pery J, Raiskup F, Ilsar M, Landau D, Orucov F, Solomon A. Conjunctival autografting combined with low-dose mitomycin $\mathrm{C}$ for prevention of primary pterygium recurrence. Am J Ophthalmol. 2006; 141(6):1044-1050.

70. Segev F, Jaeger-Roshu S, Gefen-Carmi N, Assia EI. Combined mitomycin $\mathrm{C}$ application and free flap conjunctival autograft in pterygium surgery. Cornea. 2003;22(7):598-603.

71. Tseng SC, Li DQ, Ma X. Suppression of transforming growth factor-beta isoforms, TGF-beta receptor type II, and myofibroblast differentiation in cultured human corneal and limbal fibroblasts by amniotic membrane matrix. J Cell Physiol. 1999;179(3):325-335.

72. Lee SB, Li DQ, Tan DT, Meller DC, Tseng SC. Suppression of TGFbeta signaling in both normal conjunctival fibroblasts and pterygial body fibroblasts by amniotic membrane. Curr Eye Res. 2000;20(4): 325-334.

73. Prabhasawat P, Barton K, Burkett G, Tseng SC. Comparison of conjunctival autografts, amniotic membrane grafts, and primary closure for pterygium excision. Ophthalmology. 1997;104(6):974-985.

74. Sangwan VS, Burman S, Tejwani S, Mahesh SP, Murthy R. Amniotic membrane transplantation: a review of current indications in the management of ophthalmic disorders. Indian J Ophthalmol. 2007;55(4):251-260.

75. Thatte S. Amniotic membrane transplantation: an option for ocular surface disorders. Oman J Ophthalmol. 2011;4(2):67-72.

76. Arain MA, Yaqub MA, Ameen SS, Iqbal Z, Naqvi AH, Niazi MK. Amniotic membrane transplantation in primary pterygium compared with bare sclera technique. J Coll Physicians Surg Pak. 2012;22(7):440-443.

77. Moreno-López R. Estudio comparativo entre escisión de pterigión primario con autoinjerto conjuntival, membrana amniótica y cierre primario [Comparative study between primary pterygium excision using conjunctival autograft, amniotic membrane, and primary closure] Rev Mex Oftalmol. 2004;78:291-297.

78. Solomon A, Pires RT, Tseng SC. Amniotic membrane transplantation after extensive removal of primary and recurrent pterygia. Ophthalmology. 2001;108(3):449-460.

79. Clearfield E, Hawkins BS, Kuo IC. Conjunctival autograft versus amniotic membrane transplantation for treatment of pterygium: findings from a Cochrane systematic review. Am J Ophthalmol. 2017;182:8-17.

80. Tananuvat N, Martin T. The results of amniotic membrane transplantation for primary pterygium compared with conjunctival autograft. Cornea. 2004;23(5):458-463.

81. Özer A, Y1ldırım N, Erol N, Yurdakul S. Long-term results of bare sclera, limbal-conjunctival autograft and amniotic membrane graft techniques in primary pterygium excisions. Ophthalmologica. 2009;223(4):269-273.

82. Keklikci U, Celik Y, Cakmak SS, Unlu MK, Bilek B. Conjunctivallimbal autograft, amniotic membrane transplantation, and intraoperative mitomycin C for primary pterygium. Ann Ophthalmol. 2007;39(4): 296-301.

83. Besharati MR, Miratashi SA, Ahmadi AB. Pterygium surgery: amniotic membrane or conjunctival autograft transplantation. Int J Ophthalmol. 2006;6:1258-1262.

84. Hao Y, Ma DH, Hwang DG, Kim WS, Zhang F. Identification of antiangiogenic and antiinflammatory proteins in human amniotic membrane. Cornea. 2000;19(3):348-352.

85. Bultmann S, You L, Spandau U. Amniotic membrane downregulates chemokine expression in human keratocytes. Investig Ophthalmol Vis Sci. 1999;40:S578.

86. Tseng SC, Li DQ, Ma X. Suppression of transforming growth factor-beta isoforms, TGF-beta receptor type II, and myofibroblast differentiation in cultured human corneal and limbal fibroblasts by amniotic membrane matrix. J Cell Physiol. 1999;179(3):325-335.

87. Ye J, Kook KH, Yao K. Temporary amniotic membrane patch for the treatment of primary pterygium: mechanisms of reducing the recurrence rate. Graefes Arch Clin Exp Ophthalmol. 2006;244(5):583-588.
88. Katırcıoglu YA, Altiparmak U, Engur Goktas S, Cakir B, Singar E, Ornek F. Comparison of two techniques for the treatment of recurrent pterygium: amniotic membrane vs conjunctival autograft combined with mitomycin C. Semin Ophthalmol. 2015;30(5-6):321-327.

89. Amano S, Motoyama Y, Oshika T, Eguchi S, Eguchi K. Comparative study of intraoperative mitomycin $\mathrm{C}$ and beta irradiation in pterygium surgery. Br J Ophthalmol. 2000;84(6):618-621.

90. Rosen R. Amniotic membrane grafts to reduce pterygium recurrence. Cornea. 2018;37(2):189-193.

91. Cho H, Chuck RS. Pterygium excision and placement of amniotic membrane grafts. In: Hovanesian JA, editor. Pterygium: Techniques and Technologies for Surgical Success. Thorofare, NJ: Slack Inc; 2012:91-100.

92. Ghanavati SZ, Shousha MA, Betancurt C, Perez VL. Combined conjunctival autograft and overlay amniotic membrane transplantation; a novel surgical treatment for pterygium. JOphthalmic Vis Res. 2014;9(3): 399-403.

93. Shimazaki J, Kosaka K, Shimmura S, Tsubota K. Amniotic membrane transplantation with conjunctival autograft for recurrent pterygium. Ophthalmology. 2003;110(1):119-124.

94. Pan X, Zhang D, Jia Z, Chen Z, Su Y. Comparison of hyperdry amniotic membrane transplantation and conjunctival autografting for primary pterygium. BMC Ophthalmol. 2018;18(1):119.

95. Okabe M, Kitagawa K, Yoshida T, et al. Hyperdry human amniotic membrane is useful material for tissue engineering: physical, morphological properties, and safety as the new biological material. J Biomed Mater Res A. 2014;102(3):862-870.

96. Allen CL, Clare G, Stewart EA, et al. Augmented dried versus cryopreserved amniotic membrane as an ocular surface dressing. PLoS One. 2013;8(10):e78441

97. McCoombes JA, Hirst LW, Isbell GP. Sliding conjunctival flap for the treatment of primary pterygium. Ophthalmology. 1994;101(1):169-173.

98. Alpay A, Ugurbas SH, Erdogan B. Comparing techniques for pterygium surgery. Clin Ophthalmol. 2009;3:69-74.

99. Bamdad S, Kooshki AS, Yasemi M. Surgical outcome of conjunctival rotational autograft-mitomycin $\mathrm{C}$ (MMC) versus free conjunctival autograft-MMC for pterygium removal: a randomized clinical trial. Electron Physician. 2017;9(12):5877-5884.

100. Dadeya S, Malik KP, Gulliani BP. Pterygium surgery: conjunctival rotation autograft versus conjunctival autograft. Ophthalmic Surg Lasers. 2002;33:269-274.

101. Wu WK, Wong VW, Chi SC, Lam DS. Surgical management of double-head pterygium by using a novel technique: conjunctival rotational autograft combined with conjunctival autograft. Cornea. 2007;26(9):1056-1059.

102. Jap A, Chan C, Lim L, Tan DT. Conjunctival rotation autograft for pterygium. An alternative to conjunctival autografting. Ophthalmology. 1999;106(1):67-71.

103. Young AL, Tam PM, Leung GY, Cheng LL, Lam PT, Lam DS. Prospective study on the safety and efficacy of combined conjunctival rotational autograft with intraoperative $0.02 \%$ mitomycin $\mathrm{C}$ in primary pterygium excision. Cornea. 2009;28(2):166-169.

104. Almond MC, Dastrup BT, Kaufman SC. 5-Fluorouracil and mitomycin $\mathrm{C}$ : adjuncts to pterygium surgery. In: Hovanesian JA, editor. Pterygium: Techniques and Technologies for Surgical Success. Thorofare, NJ: Slack Inc; 2012:55-64.

105. Hayasaka S, Noda S, Yamamoto Y, Setogawa T. Postoperative instillation of low-dose mitomycin $\mathrm{C}$ in the treatment of primary pterygium. Am J Ophthalmol. 1988;106(6):715-718.

106. Frucht-Pery J, Ilsar M, Hemo I. Single dosage of mitomycin C for prevention of recurrent pterygium: preliminary report. Cornea. 1994; 13(5):411-413.

107. Mahar PS. Conjunctival autograft versus topical mitomycin $\mathrm{C}$ in treatment of pterygium. Eye. 1997;11(Pt 6):790-792.

108. Manning CA, Kloess PM, Diaz MD, Yee RW. Intraoperative mitomycin in primary pterygium excision. A prospective, randomized trial. Ophthalmology. 1997;104(5):844-848. 
109. Sharma A, Gupta A, Ram J, Gupta A. Low-dose intraoperative mitomycin-C versus conjunctival autograft in primary pterygium surgery: long term follow-up. Ophthalmic Surg Lasers. 2000;31(4): 301-307.

110. Keklikci U, Celik Y, Cakmak SS, Unlu MK, Bilek B. Conjunctivallimbal autograft, amniotic membrane transplantation, and intraoperative mitomycin C for primary pterygium. Ann Ophthalmol. 2007; 39(4):296-301.

111. Ari S, Caca I, Yildiz ZÖ, Sakalar YB, Dogan E. Comparison of mitomycin $\mathrm{C}$ and limbal-conjunctival autograft in the prevention of pterygial recurrence in Turkish patients: a one-year, randomized, assessor-masked, controlled trial. Curr Ther Res Clin Exp. 2009;70(4): 274-281.

112. Biswas MC, Shaw C, Mandal R. Treatment of pterygium with conjunctival limbal autograft and mitomycin $\mathrm{C}$ - a comparative study. J Indian Med Assoc. 2007;105(4):200 ,202, 204.

113. Koranyi G, Artzén D, Seregard S, Kopp ED. Intraoperative mitomycin $\mathrm{C}$ versus autologous conjunctival autograft in surgery of primary pterygium with four-year follow-up. Acta Ophthalmol. 2012; 90(3):266-270.

114. Cardillo JA, Alves MR, Ambrosio LE, Poterio MB, Jose NK. Single intraoperative application versus postoperative mitomycin C eye drops in pterygium surgery. Ophthalmology. 1995;102(12):1949-1952.

115. Helal M, Messiha N, Amayem A, El-Maghraby A, Elsherif Z, Dabees M. Intraoperative mitomycin-C versus postoperative topical mitomycin-C drops for the treatment of pterygium. Ophthalmic Surg Lasers. 1996;27(8):674-678.

116. Hosal BM, Gürsel E. Mitomycin-C for prevention of recurrent pterygium. Ann Ophthalmol. 2000;32(2):107-109.

117. Oguz H, Basar E, Gurler B. Intraoperative application versus postoperative mitomycin $\mathrm{C}$ eye drops in pterygium surgery. Acta Ophthalmol Scand. 1999;77(2):147-150.

118. Frucht-Pery J, Ilsar M. The use of low-dose mitomycin C for prevention of recurrent pterygium. Ophthalmology. 1994;101(4):759-762.

119. Dougherty PJ, Hardten DR, Lindstrom RL. Corneoscleral melt after pterygium surgery using a single intraoperative application of mitomycin-C. Cornea. 1996;15(5):537-540.

120. Dushinsky R, Pleven E, Heidelberger C. The synthesis of 5-fluoropyrimidines. J Am Chem Soc. 1957;79:4559-4560.

121. Smith S, D'Amore PA, Dreyer EB. Comparative toxicity of mitomycin C and 5-fluorouracil in vitro. Am J Ophthalmol. 1994;118(3): 332-337.

122. Valezi VG, Schellini SA, Hata Viveiros MM, Padovani CR. Segurança e efetividade no tratamento do pterígio usando infiltração de 5-fluoruracila no intraoperatorio [Safety and efficacy of intraoperative 5-fluorouracil infiltration in pterygium treatment]. Arq Bras Oftalmol. 2009;72:169-173. Portuguese.

123. Akarsu C, Taner P, Ergin A. 5-Fluorouracil as chemoadjuvant for primary pterygium surgery: preliminary report. Cornea. 2003;22(6): 522-526.

124. Pikkel J, Porges Y, Ophir A. Halting pterygium recurrence by postoperative 5-fluorouracil. Cornea. 2001;20(2):168-171.

125. Prabhasawat $P$, Tesavibul N, Leelapatranura K, Phonjan T. Efficacy of subconjunctival 5-fluorouracil and triamcinolone injection in impending recurrent pterygium. Ophthalmology. 2006;113(7):1102-1109.

126. Galentine P, Sloas H, Hargett N, Cupples HP. Bilateral cicatricial ectropion following topical administration of 5-fluorouracil. Ann Ophthalmol. 1981;13(5):575-577.

127. Caravella LP, Burns JA, Zangmeister M. Punctal-canalicular stenosis related to systemic fluorouracil therapy. Arch Ophthalmol. 1981;99(2): 284-286.

128. Hickey-Dwyer M, Wishart PK. Serious corneal complication of 5-fluorouracil. Br J Ophthalmol. 1993;77(4):250-251.

129. Weinreb RN. Adjusting the dose of 5-fluorouracil after filtration surgery to minimize side effects. Ophthalmology. 1987;94(5):564-570.

130. Burk A. Die Behandlung der Homhaut epitheliome durch Rontgenstrahlen. Strahlenther Onkol. 1912;1:168-171.
131. Jaros PA, Deluise VP. Pingueculae and pterygium. Surv Ophthalmol. 1988;32:41-49.

132. Jürgenliemk-Schulz IM, Hartman LJ, Roesink JM, et al. Prevention of pterygium recurrence by postoperative single-dose beta-irradiation: a prospective randomized clinical double-blind trial. Int J Radiat Oncol Biol Phys. 2004;59(4):1138-1147.

133. De Keizer RJ. Pterygium excision with or without postoperative irradiation, a double-blind study. Doc Ophthalmol. 1982;52(3-4):309-315.

134. Paryani SB, Scott WP, Wells JW, et al. Management of pterygium with surgery and radiation therapy. The North Florida Pterygium Study Group. Int J Radiat Oncol Biol Phys. 1994;28(1):101-103.

135. Brenner DJ, Merriam GR. Postoperative irradiation for pterygium: guidelines for optimal treatment. Int J Radiat Oncol Biol Phys. 1994; 30(3):721-725.

136. Bahrassa F, Datta R. Postoperative beta radiation treatment of pterygium. Int J Radiat Oncol Biol Phys. 1983;9(5):679-684.

137. Beyer DC. Pterygia: single-fraction postoperative beta irradiation. Radiology. 1991;178(2):569-571.

138. Cooper JS. Postoperative irradiation of pterygia: ten more years of experience. Radiology. 1978;128(3):753-756.

139. Wilder RB, Buatti JM, Kittelson JM, et al. Pterygium treated with excision and postoperative beta irradiation. Int J Radiat Oncol Biol Phys. 1992;23(3):533-537.

140. Khalfaoui T, Mkannez G, Colin D, et al. Immunohistochemical analysis of vascular endothelial growth factor (VEGF) and p53 expression in pterygium from Tunisian patients. Pathol Biol. 2011;59(3): 137-141.

141. Teng CC, Patel NN, Jacobson L. Effect of subconjunctival bevacizumab on primary pterygium. Cornea. 2009;28(4):468-470.

142. Mansour AM. Regression of inflamed pterygia by frequent high-dose intralesional ziv-aflibercept. Cornea. 2017;36(8):1002-1005.

143. Shenasi A, Mousavi F, Shoa-Ahari S, Rahimi-Ardabili B, Fouladi RF. Subconjunctival bevacizumab immediately after excision of primary pterygium: the first clinical trial. Cornea. 2011;30(11): 1219-1222.

144. Razeghinejad MR, Banifatemi M. Subconjunctival bevacizumab for primary pterygium excision; a randomized clinical trial. JOphthalmic Vis Res. 2014;9(1):22-30.

145. Shahin MM, Elbendary AM, Elwan MM, Maha M, Amal M, Mohamed M. Intraoperative subconjunctival bevacizumab as an adjunctive treatment in primary pterygium: a preliminary report. Ophthalmic Surg Lasers Imaging. 2012;43(6):459-466.

146. Stival LR, Lago AM, Figueiredo MN, Bittar RH, Machado ML, Nassaralla Junior JJ. Efficacy and safety of subconjunctival bevacizumab for recurrent pterygium. Arq Bras Oftalmol. 2014;77(1):4-7.

147. Nuzzi R, Tridico F. Efficacy of subconjunctival bevacizumab injections before and after surgical excision in preventing pterygium recurrence. J Ophthalmol. 2017;2017(11):6824670-6824677.

148. Sun Y, Zhang B, Jia X, Ling S, Deng J. Efficacy and safety of bevacizumab in the treatment of pterygium: an updated metaanalysis of randomized controlled trials. J Ophthalmol. 2018;2018: 4598173-4598179.

149. Alsmman AH, Radwan G, Abozaid MA, Mohammed UA, Abd Elhaleim NG. Preoperative subconjunctival combined injection of bevacizumab and mitomycin $\mathrm{C}$ before the surgical excision of primary pterygium: clinical and histological results. Clin Ophthalmol. 2017;11: 493-501.

150. Yalcin Tok O, Burcu Nurozler A, Ergun G, Akbas Kocaoglu F, Duman S. Topical cyclosporine A in the prevention of pterygium recurrence. Ophthalmologica. 2008;222(6):391-396.

151. Zhang Q, Bao N, Liang K, Tao L. Adjuvant use of cyclosporine a in the treatment of primary pterygium: a systematic review and metaanalysis. Cornea. 2018;37(8):1000-1007.

152. Ibáñez M, Eugarrios MF, Calderón DI. Topical cyclosporin A and mitomycin $\mathrm{C}$ injection as adjunctive therapy for prevention of primary pterygium recurrence. Ophthalmic Surg Lasers Imaging. 2009;40(3): 239-244. 
153. Aydin A, Karadayi K, Aykan U, Can G, Colakoglu K, Bilge AH. Effectiveness of topical ciclosporin A treatment after excision of primary pterygium and limbal conjunctival autograft. $J \mathrm{Fr}$ Ophtalmol. 2008;31(7):699-704.

154. Ren Y, Wang C, Lin Y. Study on topical cyclosporine A in the prevention of pterygium recurrence. Int J Ophthalmol. 2009;9:2240-2241.

155. Wang IJ, Lai WT, Liou SW, et al. Impression cytology of pterygium. J Ocul Pharmacol Ther. 2000;16(6):519-528.

156. Nakamura M, Nishida T. Differential effects of epidermal growth factor and interleukin 6 on corneal epithelial cells and vascular endothelial cells. Cornea. 1999;18(4):452-458.

157. Ebrahimi ME, Kordi-Tamandani DM, Arish M. A novel approach to investigation of the pathogenesis of pterygium based on assessment of promoter hyper-methylation and expression profile of CTLA4 gene: a credible report of CTLA4 gene expression in human eye tissue. Gene. 2016;583(2):130-133.

158. Lin H, Luo L, Ling S, et al. Lymphatic microvessel density as a predictive marker for the recurrence time of pterygium: a three-year follow-up study. Mol Vis. 2013;19:166-173.

159. Tang B, Ren H, Liu H, et al. CCR5 blockade combined with cyclosporine A attenuates liver GVHD by impairing $\mathrm{T}$ cells function. Inflamm Res. 2016;65(11):917-924.

160. Kim KW, Kim JC. Current approaches and future directions in the management of pterygium. Int J Ophthalmol. 2018;11(5): 709-711.

161. Hong HS, Lee J, Lee E, et al. A new role of substance $P$ as an injuryinducible messenger for mobilization of CD29(+) stromal-like cells. Nat Med. 2009;15(4):425-435.

162. Prat D, Zloto O, Ben Artsi E, Ben Simon GJ. Therapeutic contact lenses vs tight bandage patching and pain following pterygium excision: a prospective randomized controlled study. Graefes Arch Clin Exp Ophthalmol. 2018;256(11):2143-2148.

163. Yeung SN, Lichtinger A, Kim P, et al. Efficacy and safety of patching vs bandage lens on postoperative pain following pterygium surgery. Eye. 2015;29(2):295-296.

164. Daglioglu MC, Coskun M, Ilhan N, et al. The effects of soft contact lens use on cornea and patient's recovery after autograft pterygium surgery. Cont Lens Anterior Eye. 2014;37(3):175-177.

165. Arenas E, Garcia S. A scleral soft contact lens designed for the postoperative management of pterygium surgery. Eye Contact Lens. 2007; 33(1):9-12.

166. Ozcimen M, Sakarya Y, Goktas S, et al. Effect of nepafenac eye drops on pain associated with pterygium surgery. Eye Contact Lens. 2015; 41(3):187-189

167. Sul S, Korkmaz S, Alacamli G, Ozyol P, Ozyol E. Application of autologous serum eye drops after pterygium surgery: a prospective study. Graefes Arch Clin Exp Ophthalmol. 2018;256(10):1939-1943.

168. Fonseca EC, Rocha EM, Arruda GV. Comparison among adjuvant treatments for primary pterygium: a network meta-analysis. $\mathrm{Br} J$ Ophthalmol. 2018;102(6):748-756.

169. Bekibele CO, Baiyeroju AM, Olusanya BA, Ashaye AO, Oluleye TS. Pterygium treatment using 5-FU as adjuvant treatment compared to conjunctiva autograft. Eye. 2008;22(1):31-34.

170. Pherwani A, Vakil V, Eatamadi H, Singh R, Dua HS. Postoperative subconjunctival 5-fluorouracil in the management of recurring pterygium. Br J Ophthalmol. 2007;91(3):398-399.

171. Rachmiel R, Leiba H, Levartovsky S. Results of treatment with topical mitomycin C $0.02 \%$ following excision of primary pterygium. $\mathrm{Br} \mathrm{J}$ Ophthalmol. 1995;79(3):233-236.

172. Viani GA, Stefano EJ, de Fendi LI, Fonseca EC. Long-term results and prognostic factors of fractionated strontium-90 eye applicator for pterygium. Int J Radiat Oncol Biol Phys. 2008;72(4): 1174-1179.

173. Jürgenliemk-Schulz IM, Hartman LJ, Roesink JM, et al. Prevention of pterygium recurrence by postoperative single-dose beta-irradiation: a prospective randomized clinical double-blind trial. Int J Radiat Oncol Biol Phys. 2004;59(4):1138-1147.
174. Zeng W, Liu Z, Dai H, et al. Anti-fibrotic, anti-VEGF or radiotherapy treatments as adjuvants for pterygium excision: a systematic review and network meta-analysis. BMC Ophthalmol. 2017;17(1):211.

175. Liu J, Fu Y, Xu Y, Tseng SC. New grading system to improve the surgical outcome of multirecurrent pterygia. Arch Ophthalmol. 2012; 130(1):39-49.

176. Olusanya BA, Ogun OA, Bekibele CO, et al. Risk factors for pterygium recurrence after surgical excision with combined conjunctival autograft (CAG) and intraoperative antimetabolite use. Afr J Med Med Sci. 2014; 43(1):35-40.

177. Ha SW, Park JH, Shin IH, Kim HK. Clinical analysis of risk factors contributing to recurrence of pterygium after excision and graft surgery. Int J Ophthalmol. 2015;8(3):522-527.

178. Sandra S, Zeljka J, Zeljka VA, Kristian S, Ivana A. The influence of pterygium morphology on fibrin glue conjunctival autografting pterygium surgery. Int Ophthalmol. 2014;34(1):75-79.

179. Varssano D, Shalev H, Lazar M, Fischer N. Pterygium excision with conjunctival autograft: true survival rate statistics. Cornea. 2013;32(9): $1243-1250$.

180. Kheirkhah A, Nazari R, Nikdel M, Ghassemi H, Hashemi H, Behrouz MJ. Postoperative conjunctival inflammation after pterygium surgery with amniotic membrane transplantation versus conjunctival autograft. Am J Ophthalmol. 2011;152(5):733-738.

181. Hilmi MR, Che Azemin MZ, Mohd Kamal K, Mohd Tamrin MI, Abdul Gaffur N, Tengku Sembok TM. Prediction of changes in visual acuity and contrast sensitivity function by tissue redness after pterygium surgery. Curr Eye Res. 2017;42(6):852-856.

182. Chowers I, Pe'er J, Zamir E, Livni N, Ilsar M, Frucht-Pery J. Proliferative activity and $\mathrm{p} 53$ expression in primary and recurrent pterygia. Ophthalmology. 2001;108(5):985-988.

183. Kase S, Takahashi S, Sato I, Nakanishi K, Yoshida K, Ohno S. Expression of p27(KIP1) and cyclin D1, and cell proliferation in human pterygium. Br J Ophthalmol. 2007;91(7):958-961.

184. Kim KW, Park SH, Wee SW, Kim JC. Overexpression of angiogenin in pterygium body fibroblasts and its association with proliferative potency. Invest Ophthalmol Vis Sci. 2013;54(9): 6355-6362.

185. Riau AK, Wong TT, Lan W, Finger SN, et al. Aberrant DNA methylation of matrix remodeling and cell adhesion related genes in pterygium. PLoS One. 2011;6(2):e14687.

186. Chen KH, Hsu WM. Intraoperative ethanol treatment as an adjuvant therapy of pterygium excision. Int J Biomed Sci. 2006;2(4): 414-421.

187. Ashaye AO. Refractive astigmatism and pterygium. Afr J Med Med Sci. 1990;19(3):225-228.

188. Soriano JM, Janknecht P, Witschel H. Effect of pterygium operation on preoperative astigmatism. Prospective study. Ophthalmologe. 1993; 90(6):688-690

189. Avisar R, Mekler S, Savir H. Effect of pterygium excision on keratometric readings. Harefuah. 1994;126(2):63-65.

190. Stern GA, Lin A. Effect of pterygium excision on induced corneal topographic abnormalities. Cornea. 1998;17(1):23-27.

191. Fong KS, Balakrishnan V, Chee SP, Tan DT. Refractive change following pterygium surgery. Clao J. 1998;24(2):115-117.

192. Tomidokoro A, Oshika T, Amano S, Eguchi K, Eguchi S. Quantitative analysis of regular and irregular astigmatism induced by pterygium. Cornea. 1999;18(4):412-415.

193. Kheirkhah A, Safi H, Molaei S, Nazari R, Behrouz MJ, Raju VK Effects of pterygium surgery on front and back corneal astigmatism. Can J Ophthalmol. 2012;47(5):423-428.

194. Altan-Yaycioglu R, Kucukerdonmez C, Karalezli A, Corak F, Akova YA. Astigmatic changes following pterygium removal: comparison of 5 different methods. Indian J Ophthalmol. 2013;61(3): $104-108$

195. Gumus K, Erkilic K, Topaktas D, Colin J. Effect of pterygia on refractive indices, corneal topography, and ocular aberrations. Cornea. 2011;30(1):24-29. 
196. Gumus K, Topaktas D, Göktaş A, Karakucuk S, Oner A, Mirza GE. The change in ocular higher-order aberrations after pterygium excision with conjunctival autograft: a 1-year prospective clinical trial. Cornea. 2012;31(12):1428-1431.

197. Ozgurhan EB, Kara N, Cankaya KI, et al. Corneal wavefront aberrations after primary and recurrent pterygium surgery. Eye Contact Lens. 2015;41(6):378-381.
198. Razmjoo H, Vaezi M-H, Peyman A, Koosha N, Mohammadi Z, Alavirad M. The effect of pterygium surgery on wavefront analysis. Adv Biomed Res. 2014;3:196.

\section{Publish your work in this journal}

Clinical Ophthalmology is an international, peer-reviewed journal covering all subspecialties within ophthalmology. Key topics include: Optometry; Visual science; Pharmacology and drug therapy in eye diseases; Basic Sciences; Primary and Secondary eye care; Patient Safety and Quality of Care Improvements. This journal is indexed on

\section{Dovepress}

PubMed Central and CAS, and is the official journal of The Society of Clinical Ophthalmology (SCO). The manuscript management system is completely online and includes a very quick and fair peer-review system, which is all easy to use. Visit http://www.dovepress.com/ testimonials.php to read real quotes from published authors. 